\title{
Affective Damage to Oral Corrective Feedback among Students in Libyan Secondary Schools
}

\author{
Mohamed Elsaghayer \\ Faculty of Arts English Department Misrata University
}

\begin{abstract}
This study was carried to investigate how the learners in EFL classes emotionally react to the corrective feedback process in classroom settings and how it can affect their motivation towards the target language. For collecting the data a questionnaire was designed with ten questions and distributed among the students studying at secondary schools in Misurata, Libya. Responses to 110 valid questionnaires were analyzed. This paper first reviews the controversial role of corrective feedback in SL classrooms. Then the findings are reported and discussed. The findings show that affective damage is caused to the students, in different ways, in EFL classrooms, during the corrective feedback process. It has also found evidence that oral corrective feedback can affect the attitudes of the learners in a negative way. This paper highlights this negative aspect of the corrective feedback.

Key words: Negative Aspect Of Corrective Feedback, Affective Damage.
\end{abstract}

\section{Introduction}

In the history of teaching EFL /ESL, correction of students' errors by the teachers concerned has been an age old practice. In audio-lingual teaching classrooms 'correct' pronunciation was the main focus of correction. But with the emergence of the communicative approach, the emphasis was more on acquiring fluency and it was believed that intervening in students' errors would have a negative effect on them. Then it was noticed that non-correction of errors led to their fossilization, Selinker, L (1972), Selinker, L., \&Lakshamanan, U. (1992), often resulting in intelligibility problem. Therefore, it was felt by the teachers and scholars that the errors should be corrected. Then what exactly is corrective feedback?

It is necessary to state that errors are a natural part of the learning process(Thornberg 2005). Errors are common characteristics of language acquisition and learning. That is to say every one will make errors in the process of learning, no matter whether one is learning the first language or the second language. When students speak SL they make many errors and if these errors are not corrected, students will mistake them to be correct and internalize them to their interlanguage system. So the oral language will be easily fossilized if the teachers do not provide corrective feedback. Chaudron (1977), considers it as "any reaction of the teacher which clearly transforms, disapprovingly refers to, or demands improvement of the learner utterance,(P.31). Ellis, Loewen and Erlam (2006) describe corrective feedback as follows:

Corrective feedback takes the form of responses to learner utterances that contain error. The responses can consist of (a) an indication that an error has been committed, (b) provision of the correct language form , or (c) metalinguistic information about the nature of the error, or any combination of these. (P.340)

Lyster and Ranta (1997), classified the errors and gave a methodology to investigate the same. Following their study many researchers have investigated the corrective feedback (CF) and the students' uptake. While the results of some of these studies show that CF has a positive effect on oral accuracy, there are others which contradict this claim. One aspect of the corrective feedback which has not been sufficiently examined is how emotionally damaging it is for the learners to receive feedback, or how negatively the learners receive it. This study intends to explore that aspect.

\section{Statement of the problem}

Empirical study shows that though the corrective feedback has a positive role in improving SL learners' interlanguage, it can affect them emotionally. Even when the correction takes place at one to one level between the teacher and the learner, the latter often feels embarrassed or humiliated to be corrected before their peers. The corrective feedback, though well intended, often becomes a demotivating factor in SL classrooms. Because of this it has been seen that some learners cease or hesitant to speak in the class .

\section{Research questions}

Notwithstanding the facilitative role of the corrective feedback in EFL classrooms, the main focus of this research will be on how the learners feel affected emotionally when they receive corrective feedback from their teachers and how it will shape their attitudes and motivations towards L2 learning. This aspect of the 
impact of corrective feedback has not been much explored, and therefore, this research intends to fill this gap in the research literature. Accordingly, the present study aims to answer the following questions:

1. How are the students affected emotionally by the oral feedback process?

2. Does affective damage caused by oral feedback adversely affect EFL learners' motivations and attitudes towards L2 learning?

\section{Significance of the study}

Though several studies have been conducted concerning the positive role the corrective feedback plays in improving the target language acquisition (EFL/ESL), there has not been sufficient research literature concerning the affective damage the corrective feedback can cause. This study, by throwing light on this aspect of the corrective feedback, therefore, assumes great significance. The results of this study will create an awareness among the teachers that corrective feedback can emotionally damage a learner.

\section{Related Literature}

The purpose of corrective feedback is to draw the attention of the students to errors in their interlanguage so that they take note of the errors and learn the correct forms. Lyster and Ranta (1997), who studied the corrective feedback in French immersion classes put forward six types feedback : recast, elicitation, clarification request, repetition, explicit clarification and metalinguistic feedback. Following the publication of their study, several researchers have investigated the beneficial and non-beneficial role of corrective feedback.

Controversy concerning corrective feedback.

Ellis (2009), highlights five main controversies regarding corrective feedback which can be formulated in questions: 1. Does CF contribute to L2 acquisition? 2. Which errors are to be corrected? 3 . Who should correct? ( the teacher or the learner herself/himself) 4. Which type of CF is most effective? And, when is it better to do CF? ( Mendez. E.H Et al 2010)

It must be noted that the value attributed to CF vary depending upon the method or approach employed in providing the corrective feedback and the belief s about the correction in the language pedagogy. While in the audiolingual method the employed for correction was explicit, in the post method era the language teaching methodologists do not prescribe overt CF, according to Ellis(2009). But while some acknowledge the cognitive contribution it can make other scholars warn about the affective damage it can cause.

Some researchers (Alijaafreh\&lantolf, 1994; Doughty \& Valera, 1998; Ellis, 1993, 1994; Long, 1996Schmidt, 1990,1993, 1995) began to assert explicit grammar instruction, error correction and focus on form could promote SLA better. Other researchers Loewen et al (2009) claim that the controversy surrounding the CF can be better understood in terms of meaning-focused instruction versus form-focused instruction. The former assumes that the L2 acquisition occurs unconsciously and implicitly like the first language acquisition L1. They believe that comprehensible input and a low affective filter in the learner are essential for language learning. They claim that overt attention to linguistic form is not needed and believe that corrective feedback is ineffective ( e.g., Krashen,1981; Newmark\&Reibel, 1968; Schwartz, 1993; Truscott,1999; all cited by Loewen et al, 2009). Krashen suggests that CF is potentially harmful. And, it may also damage the feeling of he learners(Martínez 2008; Ellis 2009a; Storch 2010; Ayedh\& Khaled 2011)

So the question is this : should CF, therefore, be abandoned? Research suggests that even after years of corrective feedback learners' language shows grammatical inaccuracy. In this context it is necessary to bring in 'noticing hypothesis'. Schmidt $(1995,2001)$ draws on the concept and emphasizes the importance of noticing as paramount to language acquisition. Learners must consciously notice input for language learning to occur. From this point of view corrective feedback is necessary as it stimulates 'noticing'

Negative effects of corrective feedback.

Corrective feedback is a highly complex instructional and interactive phenomenon that manifests cognitive, social and psychological dimensions (Ellis, 2009a). Most researchers acknowledge the cognitive contribution corrective feedback can make due to its facilitative role in L2 learning, whereas others issue warnings about the potential affective damage oral corrective feedback can cause among L2 learners in classroom situations (Ellis 2009a; Ayedh\& Khaled, 2011). In this respect, Ellis (2009a) reminds us that corrective feedback does not function as 'punishment' but it may inhibit or discourage learning. Second language pedagogy has highlighted the importance of positive feedback or reinforcement in providing affective support to the learner by stimulating motivation to continue learning (Ellis 2009a). Positive feedback or reinforcement is obviously something that is very important to the students. In fact, learners need to constantly feel encouraged to keep on learning. In contrast, negative evidence provided through corrective feedback may, at times, seriously damage learners' feelings and attitudes (Martínez, 2008). Accordingly, the potential affective damage corrective feedback can cause among learners needs to be seriously taken into consideration. In short, learner individual characteristics and affective tive aspects ofaspects may influence the effectiveness of corrective feedback. A growing body of qualitative case study research has highlighted the importance of these factors in explaining learners' responses to the teacher's feedback (see Hyland 2003; Hyland \& Hyland 2006). 
Emotions and feelings towards the feedback process are mainly dependent upon how feedback is actually managed (Ayedh\& Khaled, 2011). Can oral corrective feedback, if used frequently, upset and discourage EFL learners? Of course it can. The question is how and how much. The fact is that corrective feedback can only be used to a limited extent, after which it can become discouraging and destructive (Ayedh\& Khaled, 2011), even though too little can be equally counterproductive. Corrective feedback, if used too frequently, can be negative in terms of motivation and attitude and, accordingly, should be avoided at all cost. In fact, overcorrection could undermine the student's self-confidence. According to Storch (2010, 43), "Providing feedback on a large number of errors may overwhelm the learners, not to mention be extremely time consuming for the teachers". In this sense, teachers should know when and how to correct errors and, above all, should consider learners' sensitiveness and personality. Despite the fact that most learners find corrective feedback highly helpful and, thus, need and wish to be corrected regularly in class (Schulz, 2001; Havranek, 2002; Zacharias 2007; Lyster et al. 2013), the fact is that many of them also find corrections embarrassing to varying degrees. What language teachers should actually avoid is to make learners feel embarrassed or frustrated when being orally corrected in class-fronted situations. Most importantly, the teacher should be positive and kind. Rather, corrective feedback should always be delivered carefully and in a very positive way and, above all, nicely, so that students do not feel embarrassed. In this sense, corrective feedback should be used cautiously and tactfully -and not in a direct or obtrusive way-, bearing in mind students' attitudes and personalities when being orally corrected in class fronted situations. As Ayedh\& Khaled (2011, p. 216) claimed, "Feedback should always be personal, and never directed at the person's personality". Although implicit as well as explicit types of feedback have been shown to be beneficial, and both lead to learning, the fact is that implicit corrective feedback seems more desirable as learners do not feel any 'direct criticism or attack' from the correction provided and, accordingly, their emotions are not so seriously affected. Learners sometimes find the criticism associated with corrective feedback difficult to handle, which makes them resist or reject the feedback process (Ayedh\& Khaled, 2011). The fact is that corrective feedback cannot be provided in such way that students immediately react by putting themselves on the defensive. Thus, corrective feedback must be highly flexible, adapted to the individual learner and to the social/situational context (Ellis, 2009a). Given that anxiety can have a negative effect on the way learners benefit from the feedback process, L 2 teachers should be much more concerned with learners' feelings and emotions when being orally corrected in class-fronted situations. The fact is that teachers are mainly concerned about not overcorrecting their students for fear of inducing language anxiety (Lasagabaster\& Sierra, 2005). That is, they frequently worry about hurting the learners' feelings and damaging their self-esteem. Generally, the usefulness of teachers' oral corrective feedback is perceived and accepted by most learners, even though Lyster et al. (2013, p. 1) made it clear that research on corrective feedback preferences reveals "a tendency for learners to prefer receiving CF more than teachers feel they should provide it". Rather, Lyster, et al., (2013, p. 8) pointed out that "the extent to which learners want to be corrected is generally greater than teachers' wish to provide correction". This is likely due to teachers' fear of discouraging the learners. In fact, teachers believe that corrective feedback can induce language anxiety, affecting students' self-esteem and motivation in a negative manner (Dörnyei, 1994; Lasagabaster\& Sierra, 2005; Jean \&Simard, 2011). Accordingly, the oral corrective feedback provided by teachers may be sometimes seen as a potential anxiety-provoking situation. In this respect, Dörnyei (1994, p. 282) insists on the idea of error treatment without generating anxiety by suggesting that we "use motivating feedback by making our feedback informational rather than controlling; giving positive competence feedback, pointing out the value of accomplishment; and not overreacting to errors". Arnold \& Brown (1999) also view corrective feedback as one of the major causes for language learner anxiety. In short, corrective feedback must take account of learners' affective needs in the sense that teachers should be prepared to vary the way they correct in accordance with the cognitive and affective needs of the individual learner in the classroom context (Ellis 2009a). Even Ellis (2010) suggests that teachers should abandon corrective feedback if it is a source of anxiety to a learner.

Although there does not actually exist any 'ideal corrective feedback recipe', the fact is that how teachers provide corrective feedback makes the difference. In this respect, considerable disagreement seems to exist over how best to handle corrective feedback and, accordingly, it is not still possible to specify general guidelines for corrective feedback that are appropriate for all instructional contexts (Ellis, 2011). While feedback on error can be provided in a wide variety of ways, the fact is that learners also perceive and respond to corrective feedback in different ways (Lyster, et al. 1999). In this sense, Ellis (2009a) makes clear that what is best for one learner in one context will not necessarily be best for the same learner (or another learner) in a different context. Thus, Ellis (2009a) and Lyster\& Saito (2010) remind us that teachers need to adapt and adjust flexibly a wide variety of corrective feedback techniques to the particular learner's cognitive and affective needs. As is evident, this does not necessarily mean that they can correct all students in the same way. In fact, feedback on errors should be individualised, even though this evidently involves an enormous challenge for L2 teachers. What SLA research reveals is that corrective feedback strategy should be non-intrusive and unembarrasing to learners. Certainly, the effects of corrective feedback strategies have received a great deal of attention in SLA research (Lyster and Ranta, 1997; Iwashita 2003; Lyster 2004; Loewen 2004; Sheen 2004; Truscott 2004, 2007; Bitchener et al. 2005; Ellis \& Sheen 2006; Ellis et al. 2008; Ellis 2009a, 2009b; Farrokhi\&Sattarpour, 2012). Bearing in mind the considerable 
effort and time devoted to corrective feedback, the fact is that we know so little about it. Differences in opinions are evident in responses to the key issues facing teachers and teacher educators, such as whether corrective feedback contributes to L2 acquisition, which errors to correct, who should do the correcting (the teacher or the learner him/herself), which type of corrective feedback is the most effective, and what is the best timing for corrective feedback -immediate or delayed- (Ellis, 2009a). In fact, there does not exist a unifying view of corrective feedback in SLA research due mainly to theoretical disputations and different research findings. Although most SLA research studies suggest evidence of the efficacy of corrective feedback (Han 2002; Chandler, 2003; Lyster 2004; Bitchener et al. 2005; Sheen, 2007; Bitchener\&Knoch, 2009), Hyland and Hyland, (2006, p. 84) claimed that "it is difficult to draw any clear conclusions and generalizations from the literature as a result of varied populations, treatments and research designs". Particularly, limitations in the design (see Guenette, 2007; Bitchener 2008 for discussion of these issues) and differences in their contexts and in the proficiency level of their participants make it difficult to assess the value of the claims made (Farrokhi\&Sattarpour 2012). In short, further research on the emotional damage or impact associated with oral corrective feedback in L2 classrooms is actually needed.

\section{Participants}

\section{Methodology}

The present research study was carried out in secondary schools located in Misurata, a commercial town in Libya. For collecting the data, three classes each from two secondary schools were randomly selected. A total of 120 students participated in the investigation voluntarily. After receiving 120 questionnaires, the researcher discarded 10 invalid questionnaires which were either incomplete or failed to follow the instructions of the questionnaire. Accordingly, the valid response rate was $95.85 \%$ and a total of 110 questionnaires were identified as valid data for statistical analysis in the present study. A sample of $110 \mathrm{EFL}$ learners in secondary school was employed, of these $45(49.9 \%)$ were males and $65(59.9 \%)$ were females. Of the 110 students $60(50 \%)$ were in the second year and $60(50 \%)$ were in the third year. Their average age was 17, ranging from seventeen to nineteen. Additionally, the participants in the survey had studied English for an average of 5 years. The average classroom level was lower intermediate.

\section{Instrument and data collection procedure}

Data collection took place during the scheduled class time in April 2014. A short 10 item questionnaire was specially designed for this purpose to gather information on how EFL learners emotionally react to the oral feedback process in classroom situations. A thorough content analysis and pilot test were performed to ensure the reliability and validity of the questionnaire. Before designing the final the questionnaire, a critical review of the questionnaire was also conducted by other subject matter experts to obtain suggestions for improvement. Particularly, the wording of statements is essential in ensuring we obtain the information required to answer our research questions. In this respect, ambiguous wording must be avoided so as to avoid possible erroneous responses. The questionnaire was administered by the researcher himself, who explained the purpose and potential usefulness of the survey and also made it clear to the participants that their responses would be used for research purposes only. After reminding our group of informants of the importance of giving honest answers, they were assured of the confidentiality of the data. The questionnaires were completed anonymously in class and handed back on completion.

\section{Analysis and discussion of results}

Quantitative data from the questionnaire were only utilized for descriptive statistics to answer the aforementioned research questions. Table-1displays the results of descriptive statistics.

Statements ( See the Table 1 below for the analysis)

\begin{tabular}{|l|l|l|l|l|l|l|}
\hline total & $\begin{array}{l}\text { Strongly } \\
\text { disagree }\end{array}$ & agree & $\begin{array}{l}\text { Neither agree } \\
\text { Nor disagree }\end{array}$ & Disagree & $\begin{array}{l}\text { Strongly } \\
\text { agree }\end{array}$ & $\begin{array}{l}\text { No. of } \\
\text { statements }\end{array}$ \\
\hline $100 \%$ & $14 \%$ & $50 \%$ & $22 \%$ & $7 \%$ & $5 \%$ & 1. I feel I have learnt a lot from oral correction \\
\hline 100 & 30 & 55 & 10 & 5 & $0 \%$ & 2. Oral feedback provided is necessary and helpful. \\
\hline 100 & 17 & 45 & 30 & 8 & $5 \%$ & 3. I resent when I make oral mistake. \\
\hline 100 & 18 & 45 & 20 & 13 & 4 & 4 I worry about making oral mistakes in language class. \\
\hline 100 & 15 & 30 & 27 & 16 & 12 & 5. I hate oral mistakes because I start doubting myself \\
\hline 100 & 0 & 3.3 & 13.7 & 43.5 & 40.5 & $\begin{array}{l}\text { 6. I resent being orally corrected by the teacher in the } \\
\text { classroom }\end{array}$ \\
\hline 100 & 22.5 & 39.5 & 14.5 & 15.5 & 8 & $\begin{array}{l}7 \text { I get upset when I don't understand what the teacher is } \\
\text { correcting }\end{array}$ \\
\hline 100 & 14 & 19 & 36.5 & 23.5 & 7 & 8. I am afraid that my teacher will correct every mistake \\
\hline
\end{tabular}


9. What is your immediate feeling when the teacher corrects your error?

\begin{tabular}{|l|l|l|}
\hline \multirow{5}{*}{$100 \%$} & $22 \%$ & a.I feel embarrassed \\
\cline { 2 - 3 } & $13 \%$ & b. I feel angry \\
\cline { 2 - 3 } & $10 \%$ & c. I feel happy \\
\cline { 2 - 3 } & $40 \%$ & d. I feel satisfied \\
\cline { 2 - 3 } & $03 \%$ & e. I feel nervous \\
\cline { 2 - 3 } & $12 \%$ & f. I get disturbed. \\
\hline
\end{tabular}

10 What is your immediate emotional reaction to the correction?

\begin{tabular}{|l|l|l|}
\hline \multirow{5}{*}{$100 \%$} & $10 \%$ & I wish I had not spoken \\
\cline { 2 - 3 } & $20 \%$ & I will only listen, not speak \\
\cline { 2 - 3 } & $47 \%$ & I understand the reason for error \\
\cline { 2 - 3 } & $08 \%$ & The teacher should have waited until I completed the sentence \\
\cline { 2 - 3 } & $15 \%$ & I feel insulted before my peers \\
\hline
\end{tabular}

Table 1 reports the results obtained from learners' responses with percentages of students selecting each alternative. After the data-gathering process, the next step was to synthesize and analyze the results. As displayed in Figure 1, several statements generated very high levels of agreement ('strongly agree' and 'agree').

How EFL learners emotionally respond to corrective feedback

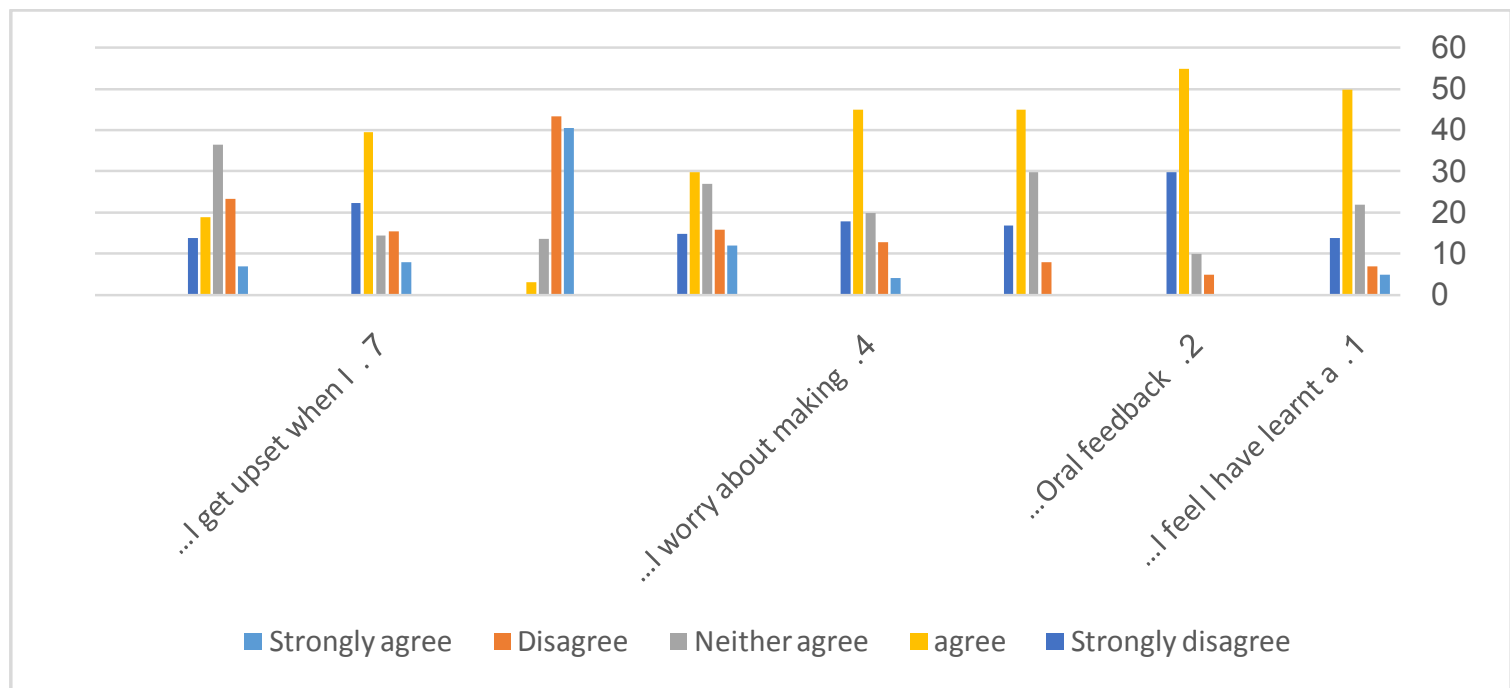

Figure1. Descriptive statistics of learners' feelings

As displayed in Table1 and illustrated in Figure1, the statement which obtained the highest percentage is statement 2 which concerns the effectiveness of the oral feedback process. In fact, most respondents (85\%) acknowledge the need and usefulness of the oral feedback provided by teachers in classroom situations. Additionally, two thirds of the participants (64\%) also recognize that they have learned a lot from the oral feedback provided (statement 1). It is somehow suggested that oral corrective feedback is essential and helpful in developing interlanguage competence.

With respect to the emotional responses derived from the oral feedback process, which is the main focus of this study, several statements provide us with useful information on to what extent teachers' oral corrective feedback emotionally influences EFL learners and how these respond or react to the oral feedback process. In this respect, we can see how nearly two-thirds of the respondents resent and worry about making oral mistakes in classroom situations $-62 \%$ and $63 \%$, respectively- (statements $3 \& 4$ ). Additionally, nearly half of the subjects surveyed (45\%) hate making oral mistakes because these make them doubt themselves and their learning possibilities (statement 5). However, while most respondents (71\%) do not resent having to be orally corrected by their teachers in the classroom (statement 6), nearly 60\% (specifically, 62\%) of the participants recognise feeling upset when they do not understand what their teachers are correcting (statement 7). Additionally, only one third of the subjects $(33 \%)$ are actually afraid that their teachers are ready to orally correct every mistake they make in class (statement 8).

In response to the question of how EFL learners actually feel when their teachers immediately correct their mistakes, several choices were considered. As illustrated in Figure2, we can see that 'feeling satisfied' becomes the top choice (40\%), followed by 'feeling embarrassed' (22\%) and then 'feeling angry' (13\%).

Statement No.9. What is your immediate feeling when the teacher corrects your error? 
Affective Damage to Oral Corrective Feedback among Students in Libyan Secondary Schools

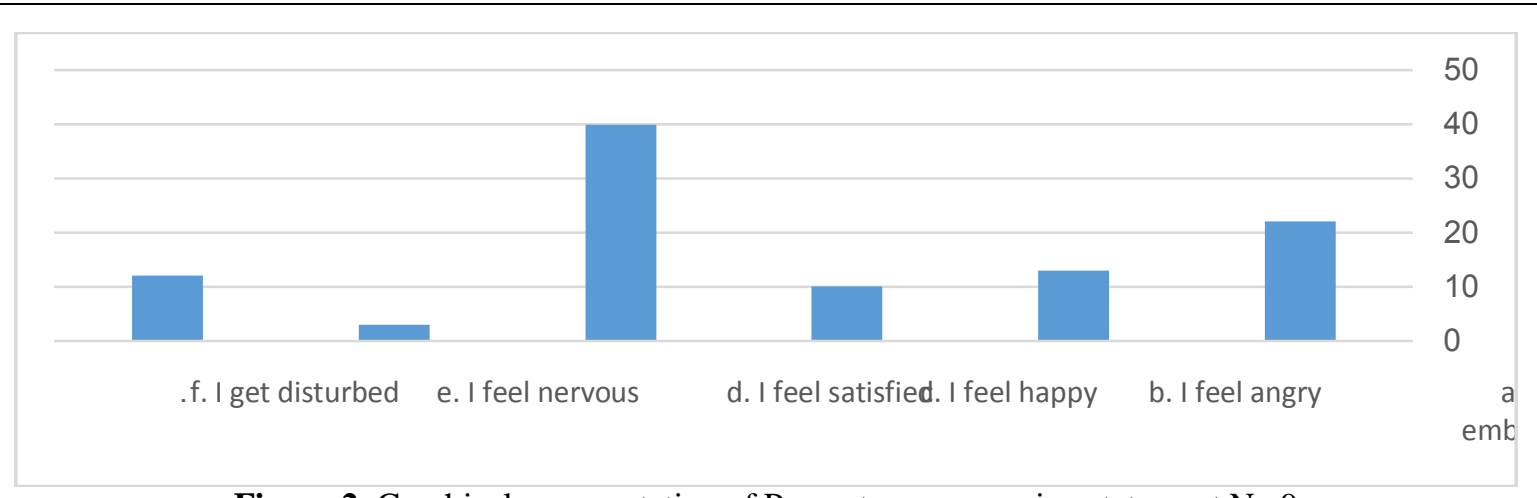

Figure 2. Graphical representation of Percentage concerning statement No.9

In response to the question of what EFL learners actually think and what they do after the teachers' immediate correction, several options were also assessed. As illustrated in Figure 3, we can see that about half of the participants understand the reasons for making the mistakes (namely, 47\%). This is the top choice, followed by their refusal to continue speaking for the rest of the lesson (20\%) and feeling insulted before the peers $(15 \%)$.

Statement No. 10. What is your immediate emotional reaction to the correction?

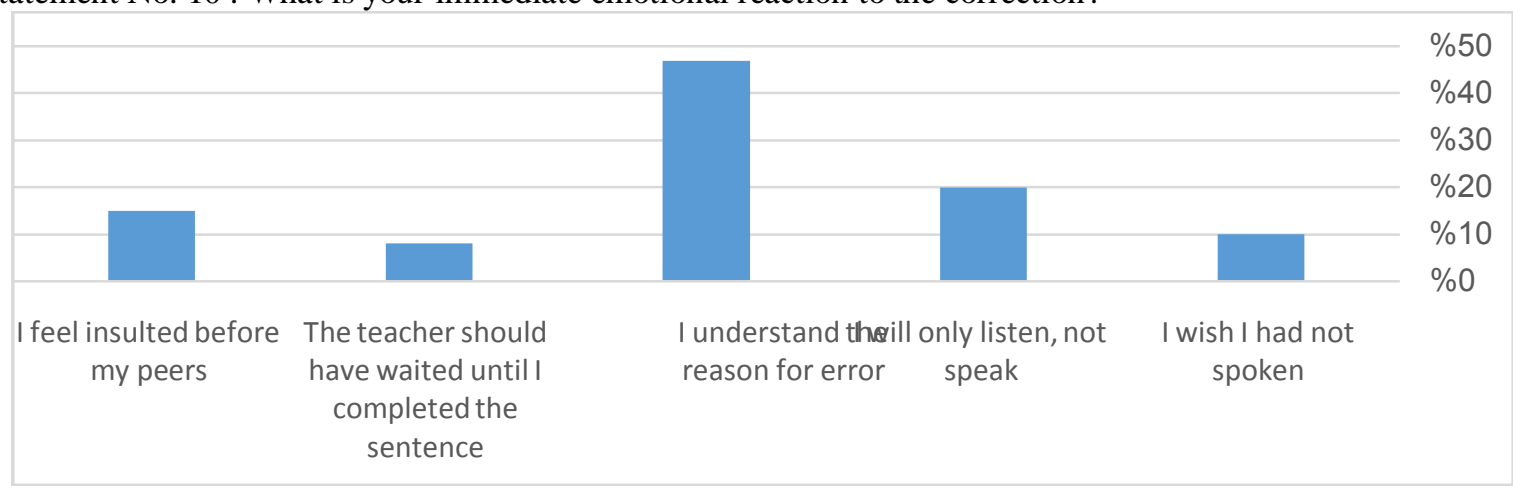

Figure 3. Graphical representation of Percentage concerning statement No.10

Although the data shown in Table 1 reveal different percentages of responses, the data obtained are consistent enough to draw several conclusions. However, several limitations in the research design make it difficult to make overall generalizations about the potential implications of this research study. Namely, the insufficient number of participants (110) could be seen as the greatest limitation of the present research study. Thus, caution should be exercised in generalizing the current findings beyond this student population, until further research investigates in more detail. Because of the very limited size of the sample, research findings call for replication on larger populations and in different teaching contexts. For future studies, a greater number of participants and the inclusion of more open-ended questions in the research instrument could be also considered. Interviews as qualitative research method would be also helpful for gathering additional data. As such, conclusions made in this study should be taken as indicative of the need for further research on the emotional aspects associated with oral corrective feedback in L2 classrooms.

\section{Conclusions and suggestions}

The main goal of this research article was to analyze how learners emotionally respond to the oral feedback process in L2 classrooms and to what extent teachers' oral corrective feedback may influence their motivations and attitudes towards L2 learning. Particularly, this research paper suggests that EFL learners emotionally respond to teachers' oral corrective feedback in different ways. Although further research would be needed as confirmation, this study revealed that most learners find teachers' oral corrective feedback highly helpful which somehow suggests that they expect and wish to be corrected regularly in classroom settings. Interestingly, however, while a high percentage of respondents resent and worry about making oral mistakes in the classroom context, most of them do not resent being orally corrected in the classroom. What actually makes them feel upset is when they do not actually understand what their teachers are correcting. Likewise, this study found evidence that some students also find oral corrective feedback inhibiting and embarrassing to varying degrees, even though a significantly higher percentage of respondents recognize that they feel satisfied with the oral feedback provided by teachers. The resulting data somehow suggests that the way teachers provide oral corrective 
feedback may influence to a certain extent learners' feelings and attitudes, particularly when these are unable to fully understand the teacher feedback, which is often ambiguous and inconsistent (Ellis 2005). Accordingly, the findings of the current study are consistent with reports from previous studies (Martínez 2008; Ellis 2009a; Storch 2010; Ayedh\& Khaled 2011) that have found that corrective feedback may damage the learners' feelings and discourage the process of learning if used very frequently. In short, the paper issues warnings about the potential affective damage oral corrective feedback can at times cause among learners in classroom situations. In this sense, we express strong reservations concerning the emotional impact that corrective feedback has on SLA.

Despite the numerous research studies on corrective feedback effectiveness conducted over the last decades, many questions still remain unanswered. Little is understood about how corrective feedback assists L2 development (Rassaei 2013). In addition to the debate about whether or not corrective feedback can be effective in classroom settings, future studies will be needed to investigate the complex of variables that affect the pedagogical effectiveness of corrective feedback in L2 classrooms (Lyster\& Saito 2010). Specifically, there is a need to investigate the effectiveness or rather the possible effects of each type of corrective feedback separately. Likewise, there is still a need for further longitudinal studies to increase our understanding of the nature of corrective feedback and its impact or differential effects on L2 learning (Iwashita 2003; Liang 2008; Bitchener\&Knoch 2010; Sheen 2010b; Farrokhi\&Sattarpour 2012). Additionally, more research into student and teacher beliefs and attitudes towards oral corrective feedback is also needed (Basturkmen et al. 2004; Lasagabaster\& Sierra 2005; Mackey et al. 2007; Montgomery \& Baker 2007; Zacharias 2007; Rassaei 2013; Lee 2013). In this respect, we recommend further studies to replicate and extend the current research framework. In order to better understand the emotional impact associated with oral corrective feedback in L2 classrooms, future studies need to adopt a more qualitative and ecologically valid research design (Storch 2010).

\section{References}

[1]. Arnold, J., \& Brown, H. D. (1999). A map of the terrain. In J. Arnold (Ed.), Affect in Language Learning (pp. 1-24). Cambridge: Cambridge University Press.

[2]. Ayedh, A., \& Khaled, E. (2011). EFL teachers' feedback to oral errors in EFL classroom: Teachers' perspectives. Arab World English Journal, 2, (1), 214-232.

[3]. Basturkmen, H., Loewen, S., \& Ellis, R. (2004). Teachers' stated belief about incidental focus on form and their classroom practices. Applied Linguistics, 25, 243-272.

[4]. Bitchener, J. (2008). Evidence in support of written corrective feedback. Journal of Second Language Writing, 17, 102-118

[5]. Bitchener, J., \&Knoch, U. (2009). The relative effectiveness of different types of direct written corrective feedback. System, (37), 322-329.

[6]. Bitchener, J., \&Knoch, U. (2010). The contribution of written corrective feedback to language development: A ten month investigation. Applied Linguistics, 31, 193-214.

[7]. Bitchener, J., Young, S., \& Cameron, D. (2005). The effect of different types of corrective feedback on ESL student writing". Journal of Second Language Writing, 14, 191-205.

[8]. Chandler, J. (2003). The efficacy of various kinds of error feedback for improvement in the accuracy and fluency of L2 student writing. Journal of Second Language Writing, 12, 267-296.

[9]. Dörnyei, Z. (1994). Motivation and motivating in the foreign language classroom. The Modern Language Journal, 78, (3), $273-284$.

[10]. Ellis, R. (2005). Instructed Second Language Acquisition: A Literature Review. Wellington, New Zealand: New Zealand Ministry of Education. Available online http://www.educationcounts.govt.nz/ data/assets/pdf file/0008/6983/instructed-second-language.pdf.

[11]. Ellis, R. (2006). Researching the effects of form-focused instruction on L2 acquisition. AILA, 19, 18-41.

[12]. Ellis, R. (2007). Corrective feedback in theory, research and practice. In: The $5^{\text {th }}$ International Conference on ELT in China \& the $1^{\text {st }}$ Congress of Chinese Applied Linguistics, May 17-20, Beijing Foreign Language Studies University, Beijing, China. Available online at http://www.celea.org.cn/2007/keynote/ppt/Ellis.pdf.

[13]. Ellis, R. (2009a). Corrective feedback and teacher development. L2 Journal, 1, 1, 3-18

[14]. Ellis, R. (2009b). A typology of written corrective feedback types. English Language Teaching Journal, 63, $97-107$.

[15]. Ellis, R. (2010). Cognitive, social and psychological dimensions of corrective feedback. In R. Batstone (Ed.), Sociocognitive Perspectives on Language Use and Language Learning (pp. 151-165). Oxford: Oxford University Press.

[16]. Ellis, R. (2011). A principled approach to incorporating second language acquisition research into a teacher education programme. Reflections on English Language Teaching, 9 (1), 1-17.

[17]. Ellis, R., \& Sheen, Y. (2006). Re-examining the role of recasts in SLA. Studies in Second Language Acquisition, 28, 575-600.

[18]. Ellis, R., Sheen, Y., Murakami, M., \& Takashima, H. (2008). The effects of focused and unfocused written corrective feedback in an English as a foreign language context". System, 36, 353-371.

[19]. Erlam, R., Ellis, R., \&Batstone, R. (2013). Oral corrective feedback on L2 writing: Two approaches compared. System, 41 (2), 257-268.

[20]. Evans, N.W., Hartshorn, K.J., McCollum, R.M., \&Wolfersberger, M. (2010). Contextualizing corrective feedback in second language writing pedagogy. Language Teaching Research, 14, 445-463.

[21]. Farrokhi, F., \&Sattarpour, S. (2012). The effects of direct written corrective feedback on improvement of grammatical accuracy on high-proficient L2 learners". World Journal of Education, 2 (2), 49-57.

[22]. Guenette, D. (2007). Is feedback pedagogically correct? Research design issues in studies of feedback on writing. Journal of Second Language Writing, 16, 40-53.

[23]. Han, Z. H. (2002). Rethinking of corrective feedback in communicative language teaching. RELC Journal, $33,1-33$.

[24]. Havranek, G. (1999). The effectiveness of corrective feedback: Preliminary results of an empirical study. Acquisition et Interaction en langue étrangère: Proceedings of the Eighth EUROSLA Conference, 2, 189-206.

[25]. Havranek, G. (2002). When is corrective feedback most likely to succeed?. International Journal of Educational Research, 37, 255-270.

[26]. Hyland, F. (2003). Focusing on form: Student engagement with teacher feedback. System, 31 (2), $217-230$. 
[27]. Hyland, K., \& Hyland, F. (2006). Feedback in Second Language Writing: Contexts and Issues. Cambridge: Cambridge University Press.

[28]. Iwashita, N. (2003). Negative feedback and positive evidence in task-based interaction: Differential effects on L2 development. Studies in Second Language Acquisition, 25 (1), 1-36.

[29]. Jean, G., \&Simard, D. (2011). Grammar learning in English and French L2: Students' and teachers' beliefs and perceptions. Foreign Language Annals, 44 (4), 465-492.

[30]. Krashen, S. (1982). Principles and Practice in Second Language Acquisition. Oxford: Pergamon Press.

[31]. Lasagabaster, D., \& Sierra, J.M. (2005). Error correction: Students' versus teachers' perceptions. Language Awareness, 14 (2-3), $112-127$.

[32]. Lee, E. J. (2013). Corrective feedback preferences and learner repair among advanced ESL students. System, 41 (2), 217-230.

[33]. Li, Sh. (2010). The effectiveness of corrective feedback in SLA: A Meta-Analysis. Language Learning, 60, 2, 309-365.

[34]. Liang, Y. (2008). The effects of error feedback in second language writing. Second Language Acquisition and Teaching, 15, 65-79.

[35]. Loewen, S. (2004). Uptake in incidental focus on form in meaning-focused ESL lessons. Language Learning, 54, 153-188.

[36]. Loewen, S., \&Erlman, R. (2006). Corrective feedback in the chatroom: An experimental study. Computer Assisted Language Learning, $19(1), 1-14$.

[37]. Loewen, S., \&Nabei, T. (2007). Measuring the effects of oral corrective feedback on L2 knowledge. In A. Mackey (Ed.), Conversational Interaction in Second Language Acquisition: A Collection of Empirical Studies (pp. 361-377). Oxford: Oxford University Press.

[38]. Lyster, R. (1998). Negotiation of form, recasts, and explicit correction in relation to error types and learner repair in immersion classrooms. Language Learning, 48, 183-218.

[39]. Lyster, R. (2004). Differential effects of prompts and recasts in form-focused instruction. Studies in Second Language Acquisition, 26, 399-432.

[40]. Lyster, R., \&Ranta, L. (1997). Corrective feedback and learner uptake: Negotiation of form in communicative classrooms. Studies in Second Language Acquisition, 20, 37-66.

[41]. Lyster, R., \& Saito, K. (2010). Oral feedback in SLA classroom research: A meta-analysis. Studies in Second Language Acquisition, $32(2), 265-302$.

[42]. Lyster, R., Lightbown, P. M., \&Spada, N. (1999). A response to Truscott's 'What's wrong with oral grammar correction'. Canadian Modern Language Review, 55 (4), 457-467.

[43]. Lyster, R., Saito, K. \&, Sato, M. (2013). Oral corrective feedback in second language classrooms. Language Teaching, 46 (1), $1-40$.

[44]. Mackey, A., \& Goo, J. (2007). Interaction research in SLA: A meta-analysis and research synthesis. In A. Mackey (Ed.), Conversational Interaction in Second Language Acquisition: A Collection of Empirical Studies (pp. 407-452). Oxford: Oxford University Press.

[45]. Mackey, A., Al-Khalil, M., Atanassova, G., Hama, M., Logan-Terry, A., Nakatsukasa, K. (2007). Teachers' intentions and learners' perceptions about corrective feedback on the L2 classroom. Innovation in Language Learning and Teaching, 1 (1), 129-152.

[46]. Mackey, A., Oliver, R., \&Leeman, J. (2003). Interactional input and the incorporation of feedback: An exploration of NS-NNS and NNS-NNS adult and child dyads. Language Learning, 53 (35)-66.

[47]. Martínez, J. D. (2008). Linguistic risk-taking and corrective feedback. In J. D. Martínez (Ed.), Oral Communication in the EFL Classroom (pp. 165-193). Sevilla: EdicionesAlfar.

[48]. Mendez.E.H, Cruz. R.R, Loyo.G.M, (2010)Memorias Del VI Foro De EstudiosEnLenguasInternacional (EFL2010)

[49]. Montgomery, J., \& Baker, W. (2007). Teacher-written feedback: Student perceptions, teacher self-assessment, and actual teacher performance. Journal of Second Language Writing, 16, 82-99.

[50]. Panova, I., \&Lyster, R. (2002). Patterns of corrective feedback and uptake in an Adult ESL classroom. TESOL Quarterly, 36, (4), 573-595

[51]. Rassaei, E. (2013). Corrective feedback, learners' perceptions, and second language development. System, 41 (2), $472-483$.

[52]. Russell, J., \&Spada, N. (2006). The effectiveness of corrective feedback for the acquisition of L2 grammar. A metaanalysis of the research. In J. M. Norris \& L. Ortega (Eds.) Synthesizing Research on Language Learning and Teaching (pp. 133-164). Philadelphia: John Benjamins.

[53]. Russell, V. (2009). Corrective feedback, over a decade of research since Lyster and Ranta (1997): Where do we stand today? Electronic Journal of Foreign Language Teaching, 6 (1), 21-31.

[54]. Schulz, R. A. (2001). Cultural differences in student and teacher perceptions concerning the role of grammar instruction and corrective feedback: USA-Columbia. Modern Language Journal, 85, 244-258.

[55]. Schwartz, B. (1993). On explicit and negative data effecting and affecting competence and linguistic behavior. Studies in Second Language Acquisition, 15, 147-163. [ [ Links ]

[56]. Selinker, L. (1972). Interlanguage. IRAL, 10, (3), 209-231.

[57]. Selinker, L., \&Lakshamanan, U. (1992). Language transfer and fossilization: The "Multiple Effects Principle". In S. M. Gass, \& L. Selinker (Eds.), Language transfer in language learning (pp. 197-216). Amsterdam: John Benjamins.

[58]. Shaofeng, L. (2010). The effectiveness of corrective feedback in SLA: A meta-analysis. Language Learning, 62, 2, 309-365.

[59]. Sheen, Y. (2004). Corrective feedback and learner uptake in communicative classrooms across instructional settings. Language Teaching Research, 8 (3), 263-300.

[60]. Sheen, Y. (2006). Exploring the relationship between characteristics of recasts and learner uptake. Language Teaching Research, 10, 361-392.

[61]. Sheen, Y. (2007). The effect of focused written corrective feedback and language aptitude on ESL learners' acquisition of articles. TESOL Quarterly, 41, 255-283.

[62]. Sheen, Y. (2010a). The role of oral and written corrective feedback in SLA. Studies in Second Language Acquisition, 32, 169-179.

[63]. Sheen, Y. (2010b). Differential effects of oral and written corrective feedback in the ESL classroom". Studies in Second Language Acquisition, 32, 203-234.

[64]. Sheen, Y., Wright, D., \&Moldawa, A. (2009). Differential effects of focused and unfocused written correction on the accurate use of grammatical forms by adult ESL learners. System, 37, 556-569.

[65]. Storch, N. (2010). Critical feedback on written corrective feedback research. International Journal of English Studies, 10 (2), 29-46.

[66]. Truscott, J. (1999). What's wrong with oral grammar correction. The Canadian Modern Language Review, 55 (4), 437-455. 
[67]. Truscott, J. (2004). Evidence and conjecture on the effects of correction: A response to Chandler. Journal of Second Language Writing, 13, 337-343.

[68]. Truscott, J. (2007). The effect of error correction on learners' ability to write accurately. Journal of Second Language Writing, 16, 255-272.

[69]. Yoshida, R. (2008). Teachers' choice and learners' preference of corrective feedback types. Language awareness, 17, 1, 78-93.

[70]. Zacharias, T.(2007).Teacher and student attitudes towards feedback. RELC Journal,38,38. 52.

Appendix

Read the following statements and rate them from 1to 5, 1 standing for ' strongly disagree and 5 standing for strongly agree, with 3 being the neutral rating.

$1=$ I strongly disagree $3=$ I neither agree

$2=$ I disagree

nor disagree

4= I strongly agree

$5=\mathrm{I}$ agree

Note: If you do not understand the question leave it blank

1.I feel I have learnt a lot from being orally corrected.

2. I think that the oral feedback provided is necessary and helpful.

3. I resent it when I commit oral errors

4. I worry about committing oral errors.

5. I hate committing oral errors because they make me doubt myself

6. I resent being orally corrected by the teacher in the class

7. I get upset when I don't understand what the teacher is correcting.

8. I am afraid that my language teacher will correct every oral mistake I make in class.

9. How do you feel when the teacher corrects the error immediately, without waiting?

a.I feel embarrassed

b. I feel angry

c. I feel happy

d. I feel satisfied

e. I feel nervous

f. I get disturbed.

10 What is your immediate emotional reaction to the correction?

1.I wish I had not spoken

2.I will only listen, not speak

3.I understand the reason for error

4.The teacher should have waited until I completed the sentence 